\title{
Trastuzumab enhances the anti-tumor effects of the histone deacetylase inhibitor sodium butyrate on a HER2-overexpressing breast cancer cell line
}

\author{
WEIWEI CHEN, FENG WEI, JING XU, YUCAI WANG, LONGBANG CHEN, \\ JINGHUA WANG and XIAOXIANG GUAN
}

Department of Medical Oncology, Jinling Hospital, Nanjing University School of Medicine, Nanjing 210002, P.R. China

Received June 14, 2011; Accepted August 9, 2011

DOI: $10.3892 /$ ijmm.2011.790

\begin{abstract}
Trastuzumab has efficacy to improve the effect of cytotoxic drugs, such as paclitaxel and anthracyclin, against HER2-overexpressing breast cancer cells. Sodium butyrate $(\mathrm{NaB})$, a histone deacetylase inhibitor, is known to have antitumoral properties. However, whether and how trastuzumab possesses the potential to synergize the anti-tumor effect of $\mathrm{NaB}$ on breast cancer cells is still equivocal. To elucidate whether combined treatment with $\mathrm{NaB}$ and trastuzumab exerts antitumor effects on a HER2-overexpressing breast cancer cell line, SKBR3 cells were treated with $\mathrm{NaB}$ alone or in combination with trastuzumab, and the effects on proliferation and cell cycle progression were analyzed. Combinatory treatment with $\mathrm{NaB}$ (4 mmol/l) and trastuzumab $(20 \mu \mathrm{g} / \mathrm{ml})$ significantly increased the growth-inhibitory effect on SKBR3 breast cancer cells, in comparison to $\mathrm{NaB}$ or trastuzumab treatment alone. The growthinhibitory effect of the combination of $\mathrm{NaB}$ and trastuzumab was accompanied by elevated mRNA and protein levels of the cyclin-dependent kinase inhibitor $\mathrm{p} 27^{\mathrm{Kip} 1}$. In contrast, this effect was absent in HER2-negative HCC1937 cells. In conclusion, trastuzumab significantly improved the antitumor effect of $\mathrm{NaB}$ on HER2-overexpressing breast cancer cell line in vitro.
\end{abstract}

\section{Introduction}

Breast cancer is second only to lung cancer as a leading cause of cancer death in women worldwide $(1,2)$. As is well known, the $H E R 2$ (c-ErbB-2, ErbB-2) gene, a marker of increased metastatic potential and decreased overall survival $(3,4)$, is amplified and overexpressed in 20-30\% of invasive breast carcinomas. The HER 2 proto-oncogene, a member of the EGFR gene family

Correspondence to: Dr Xiaoxiang Guan, Department of Medical Oncology, Jinling Hospital, Nanjing University School of Medicine, 305 East Zhongshan Road, Nanjing 210002, Jiangsu Province, P.R. China

E-mail: xguan@nju.edu.cn

Key words: breast cancer, HER2, trastuzumab, sodium butyrate, p27 $7^{\text {Kipl }}$ which also includes HER1 (ErbB-1, EGFR), HER3 (ErbB-3) and HER4 (ErbB-4), encodes a $185 \mathrm{kDa}$ transmembrane glycoprotein (2-4). A recombinant humanized monoclonal antibody, trastuzumab (Herceptin), is directed against the extracellular domain of HER2. Trastuzumab alone or in combination with chemotherapy has been shown to increase both the survival and the response rate of HER2-overexpressing metastatic breast cancers $(3,4)$. The objective response rate (ORR) of trastuzumab monotherapy ranges from $12-34 \%$ with a median duration of 9 months, which benefits the majority of breast cancer patients. Furthermore, when trastuzumab is combined with cytotoxic drugs, ORR is up to $50 \%$ in breast cancer patients (5).

However, some patients with HER2-overexpressing metastatic breast cancer who initially responded to trastuzumab will be resistant to the therapy and eventually develop disease progression. Resistance to anti-HER2 agents may occur as a result of aberrant activation of signaling pathways downstream of the receptor or the presence of truncated forms of the HER2 receptor that lack the trastuzumab binding domain. Therefore, we should overcome the resistance to develop further treatment strategies for HER2-overexpressing breast cancer (6).

Sodium butyrate $(\mathrm{NaB})$, a short chain fatty acid, belongs to the histone deacetylase inhibitor (HDACi) family. Targeting the zinc-dependent histone deacetylases (Class I and II HDACs), may induce accumulation of acetylated histones, leading to the relaxation of chromatin structure and better access for transcriptional machinery proteins. $\mathrm{NaB}$ has potent and specific anti-cancer activities (7). Clinical studies have found that the application of HDACis treatment is effective to hematopoietic malignancies and certain solid tumors, such as epithelial ovarian cancer, primary peritoneal carcinoma, non-small cell lung cancer (NSCLC), glioblastoma multiforme and breast cancer (8).

In this study, we examined the effect of $\mathrm{NaB}$ and trastuzumab on proliferation, cell cycle and apoptosis of breast cancer cell lines. Furthermore, the mRNA and protein expression of $\mathrm{p} 27^{\mathrm{Kip} 1}$ was analyzed to explore the mechanism of the potential anti-tumor effects of $\mathrm{NaB}$ and trastuzumab.

\section{Materials and methods}

Cells culture. SKBR3 human breast cancer cells (American Type Culture Collection, Manassas, VA) were maintained in 
monolayer culture in DMEM (Life Technologies, Inc., Grand Island, NY) supplemented with $10 \%$ fetal bovine serum (FBS, Hyclone, Logan, UT). HCC1937 cells were maintained in monolayer culture in DMEM supplemented with $1 \%$ vitamins, $2 \mathrm{mM}$ L-glutamine, $0.1 \mathrm{mM}$ non-essential amino acids, $1 \mathrm{mM}$ sodium pyruvate, 1\% HEPES buffer (all from Life Technologies, Inc.), and $10 \%$ fetal bovine serum (Hyclone, Thremo Scientific).

Reagents. Trastuzumab was kindly provided by Genentech (San Francisco, CA). NaB and MTT were obtained from Sigma; DMSO was purchased from Biosharp; cell cycle and apoptosis analyzing kits were acquired from Invitrogen. The rabbit anti-p27 ${ }^{\mathrm{Kip} 1}$ antibody was purchased from Cell Signaling. The rabbit anti-HER2 antibody and Alexa Fluor 488 donkey anti-rabbit IgG were purchased from Molecular Probes, Inc.

MTT assay. The MTT assay was performed as previously described (7). Cells were seeded at a density of 5,000 cells/well in a 96-well plate in triplicate for each cell line. Cells were incubated with $0,5,15,20 \mu \mathrm{g} / \mathrm{ml}$ trastuzumab, or $0,2,4,6 \mathrm{mmol} / \mathrm{l}$ $\mathrm{NaB}$ or with the combination of $4 \mathrm{mmol} / \mathrm{l} \mathrm{NaB}$ plus $20 \mu \mathrm{g} / \mathrm{ml}$ trastuzumab. Cultures were grown at $37^{\circ} \mathrm{C}$ with $5 \% \mathrm{CO}_{2}$. Fortyeight hours later, $10 \mu \mathrm{l}$ of $5 \mathrm{mg} / \mathrm{ml}$ MTT was added. Following MTT incubation for $4 \mathrm{~h}, 100 \mu \mathrm{l}$ of $100 \%$ DMSO was added and the absorbance at $490 \mathrm{~nm}$ was obtained using the 96-well plate reader (Dynex Technologies).

Flow cytometry. Cell cycle distribution and apoptosis was analyzed by flow cytometry. In brief, $1 \times 10^{6}$ cells were harvested, fixed for $30 \mathrm{~min}$ in cold ethanol (70\%), and resuspended in $1 \mathrm{ml}$ of DNA staining solution. After incubation for $30 \mathrm{~min}$ at room temperature, stained cells were analyzed with a FACSCalibur (BD Biosciences, San Jose, CA, USA), and the data were analyzed using a Modfit cell cycle analysis program.

For the apoptosis analysis, after reagent treatment, $1 \times 10^{6}$ cells were harvested and resuspended in $100 \mu \mathrm{l} 1 \mathrm{X}$ Annexinbinding buffer. In the next step $5 \mu$ Alexa Fluor 488 Annexin V and $1 \mu \mathrm{l}$ of $100 \mu \mathrm{g} / \mathrm{ml}$ PI working solution were added to each $100 \mu \mathrm{l}$ of cell suspension. Cells were incubated at room temperature for $15 \mathrm{~min}$, then $400 \mu \mathrm{l}$ of $1 \mathrm{X}$ Annexin-bonding buffer was added, and the sample was mixed gently and kept on ice. The fluorescence emission at $530 \mathrm{~nm}$ and $>575 \mathrm{~nm}$ was measured by a FACSCalibur, and the data were analyzed using a WinMDI analysis program.

Reverse transcription-PCR analysis. Total-RNA from the cells was extracted using the TRIzol reagent (Invitrogen, Carlsbad, CA, USA) and the concentration of total-RNA was measured by a spectrophotometer (BioPhotometer, Eppendorf, Hamburg, German). PrimeScript ${ }^{\mathrm{TM}}$ 1st Strand cDNA Synthesis kit (Takara, Japan) and GoTaq ${ }^{\circledR}$ Green Master Mix (Promega, Madison, WI, USA) were used for single-strand cDNA synthesis and PCR. All procedures were performed in accordance with the manufacturer's instructions. Total-RNA of $2 \mu \mathrm{g}$ was tipped out for cDNA synthesis and $20 \mu 1$ reaction volume was used for all further PCR. We used the following PCR conditions: a $94^{\circ} \mathrm{C}$ $2 \mathrm{~min}$ hot start followed by $94^{\circ} \mathrm{C}$ for $1 \mathrm{~min}, 57^{\circ} \mathrm{C}$ for $30 \mathrm{sec}$, $72^{\circ} \mathrm{C}$ for $30 \mathrm{sec}$ for 34 cycles, and a final $10 \mathrm{~min} 72^{\circ} \mathrm{C}$ extension. The following primer combinations were used for $\mathrm{p} 27^{\mathrm{Kip} 1}$, forward, 5'-gtcaaacgtaaacagctcgaat-3' and reverse, 5'-tgcata atgctacatccaacg-3'; HER2, forward, 5'-gcagctcatctaccagg agt-3' and reverse, 5'-ggcaacgtagccatcagtct-3'; and GAPDH, forward, 5'-caatgacccttcattgacc-3' and reverse, 5'-tggaagatggt gatgggatt-3'. The PCR products were electrophoresed on $2 \%$ agarose gels and detected by ethidium bromide staining.

Immunofluorescence. Endogenous p27 $7^{\text {Kip1 }}$ or HER 2 subcellular localization was detected in SKBR3 and HCC1937 cells. Cells $\left(2 \times 10^{5}\right)$ were prepared and seeded onto chamber slides, then treated with $\mathrm{NaB}$ at $4 \mathrm{mmol} / \mathrm{l}$, trastuzumab $20 \mu \mathrm{g} / \mathrm{ml}$ or $\mathrm{NaB}$ at $4 \mathrm{mmol} / 1$ plus trastuzumab at $20 \mu \mathrm{g} / \mathrm{ml} /$ well for 2 days prior to staining. Cells were then fixed with methanol/acetone $(1: 1$, $\mathrm{v} / \mathrm{v}$ ) at room temperature for $2 \mathrm{~min}$ and stained for $24 \mathrm{~h}$ at $4^{\circ} \mathrm{C}$ with rabbit anti-p27 $7^{\mathrm{Kip} 1}$ antibody or rabbit anti-HER 2 antibody, followed by $30 \mathrm{~min}$ incubation with FITC-conjugated antirabbit antibody. For all stainings, cells were incubated with $0.1 \mathrm{mg} / \mathrm{ml}$ of 4,6-diamidino-2-phenylindole (DAPI) (Sigma) to stain the nuclei. Immunofluorescence was detected using a BX50 fluorescence microscope (Olympus).

Statistical analysis. Data were expressed as mean \pm standard error of the mean. Differences between groups were compared using ANOVA, and LSD was applied for multiple means comparisons. Differences were considered significant when $\mathrm{P}<0.05$. Statistical analysis was conducted using the SPSS16.0 software.

\section{Results}

Trastuzumab sensitizes breast cancer cells to the growth inhibition of $\mathrm{NaB}$. To investigate the effects of trastuzumab and $\mathrm{NaB}$ on cellular proliferation, we analyzed the inhibitory effects of increasing concentrations of reagents on SKBR3 and HCC1937 cells by the MTT assay. Inhibition of the proliferation of SKBR3 and HCC1937 cells by treatment with $\mathrm{NaB}$ alone were time- and dose-dependent (Fig. 1A and B). Conversely, there was a slight reduction in the proliferation of SKBR3 cells exposed to $20 \mu \mathrm{g} / \mathrm{ml}$ trastuzumab for $48 \mathrm{~h}$ (Fig. 1C), whereas, there was no significant effect on the growth of HCC1937 cells, which are HER2-negative, at all concentrations of trastuzumab between 5 and $20 \mu \mathrm{g} / \mathrm{ml}$ (Fig. 1D). As described in Fig. 1E, the combination of $\mathrm{NaB}$ and trastuzumab led to a loss of SKBR3 cells up to $80 \%$. However, HCC1937 cells were not more sensitive to the combination compared with the single $\mathrm{NaB}$ group. These results showed that $\mathrm{NaB}$ and trastuzumab could highly inhibit the proliferation of HER2overexpressing SKBR3 cells.

Trastuzumab enhances the effect of $\mathrm{NaB}$ on the cell cycle and apoptosis. Cell cycle assays of SKBR3 and HCC1937 cells induced by $\mathrm{NaB}$ and trastuzumab are shown in Fig. 2. Exposure to $\mathrm{NaB}$ markedly induced cell arrest in the $\mathrm{G}_{0} / \mathrm{G}_{1}$ phase. In contrast, trastuzumab alone did not result in any significant differences in the distribution of cells in $G_{0} / G_{1}$ phase (Fig. 2) with the exception of the $20 \mu \mathrm{g} / \mathrm{ml}$ concentration, which resulted in $70.73 \%$ of the SKBR3 cells in the $\mathrm{G}_{0} / \mathrm{G}_{1}$ phase $(\mathrm{P}<0.01) \mathrm{vs}$. $71.02 \%$ in the HCC1937 cells $(\mathrm{P}>0.05)$. NaB and trastuzumab together strikingly increased the ratio of $G_{0} / G_{1}$ phase in SKBR3 breast cancer cells (Fig. 2) $(\mathrm{P}<0.05$ compared to control or single reagent alone), while similar results were not found in HCC1937 cells. In addition, the fraction of proliferating 

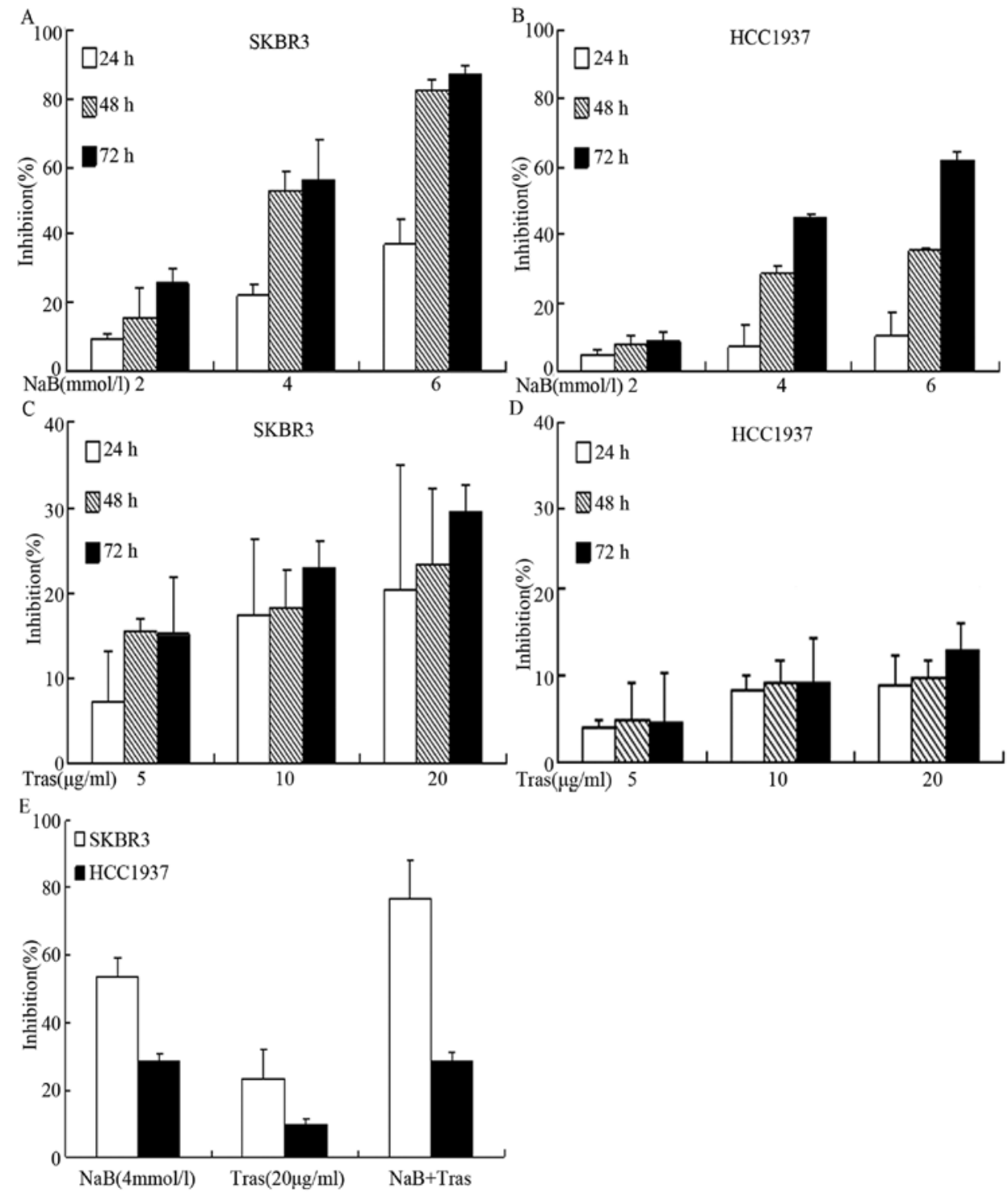

${ }^{40}[\mathrm{r} 2 \mathrm{~h}$

HCC1937

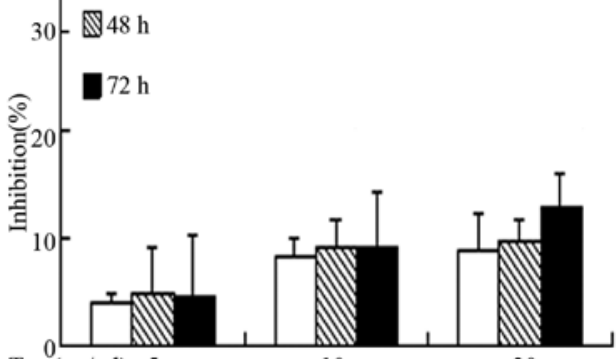

$\operatorname{Tras}(\mu \mathrm{g} / \mathrm{ml}) 5$

10

20

Figure 1. Effect of sodium butyrate (NaB) or/and trastuzumab (Tras) on proliferation of SKBR3 and HCC1937 cells. (A) Treated with different concentrations of $\mathrm{NaB}$, the proliferation of SKBR3 cells was inhibited in a time- and dose-dependent manner. (B) The effect of NaB on the proliferation of HCC1937 cells was also time- and dose-dependent. (C) Incubation with trastuzumab, inhibited the proliferation of SKBR3 cells merely until $20 \mu \mathrm{g} / \mathrm{ml}$. (D) Trastuzumab exerted a small effect on the proliferation of HCC1937 cells. (E) Compared with $\mathrm{NaB}$ alone, the combination of $\mathrm{NaB}(4 \mathrm{mmol} / \mathrm{l})$ and trastuzumab $(20 \mu \mathrm{g} / \mathrm{ml})$ treatment significantly inhibited the proliferation of SKBR3 cells. However, no similar effect was found in HCC1937 cells. "Indicates statistical significance $(\mathrm{P}<0.05)$ compared to control.
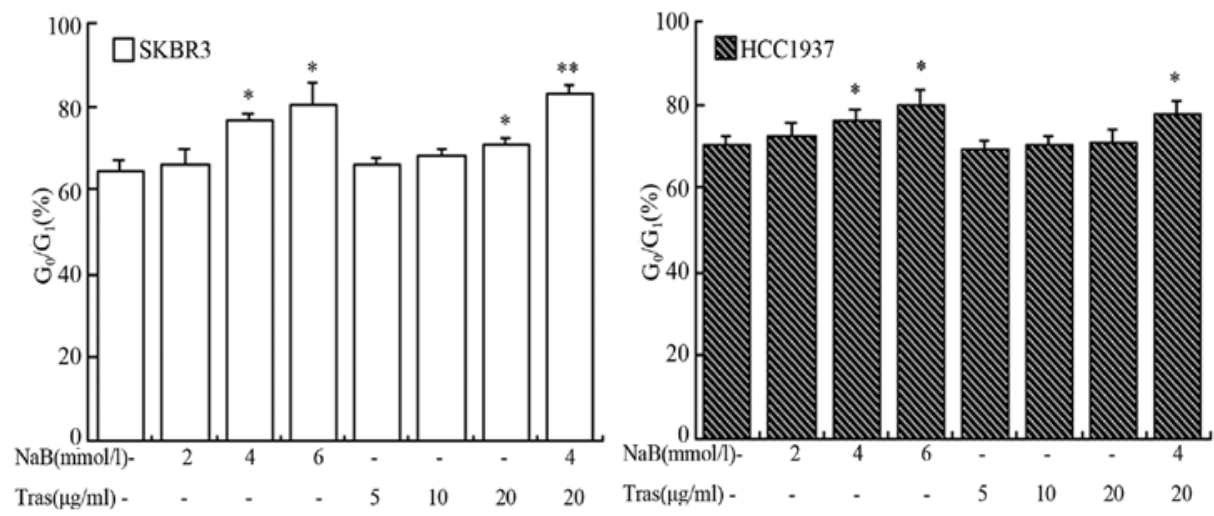

Figure 2. Flow cytometry quantitation of cell cycle of breast cancer cells incubated with sodium butyrate (NaB) or/and trastuzumab (Tras) for $48 \mathrm{~h}$. NaB induced SKBR3 cells and $\mathrm{HCC} 1937$ cells $\mathrm{G}_{0} / \mathrm{G}_{1}$ phase arrest; only trastuzumab at $20 \mu \mathrm{g} / \mathrm{ml}$ had a small effect on the cell cycle arrest of SKBR3 cells, but not of $\mathrm{HCC} 1937$ cells. The combination of $\mathrm{NaB}$ and trastuzumab increased the fraction of $\mathrm{G}_{0} / \mathrm{G}_{1}$ phase in SKBR3 cells over that induced by any reagent alone. *Statistical significance $(\mathrm{P}<0.05)$ compared to control. ${ }^{*}$ Statistical significance compared to control or any single drug. 


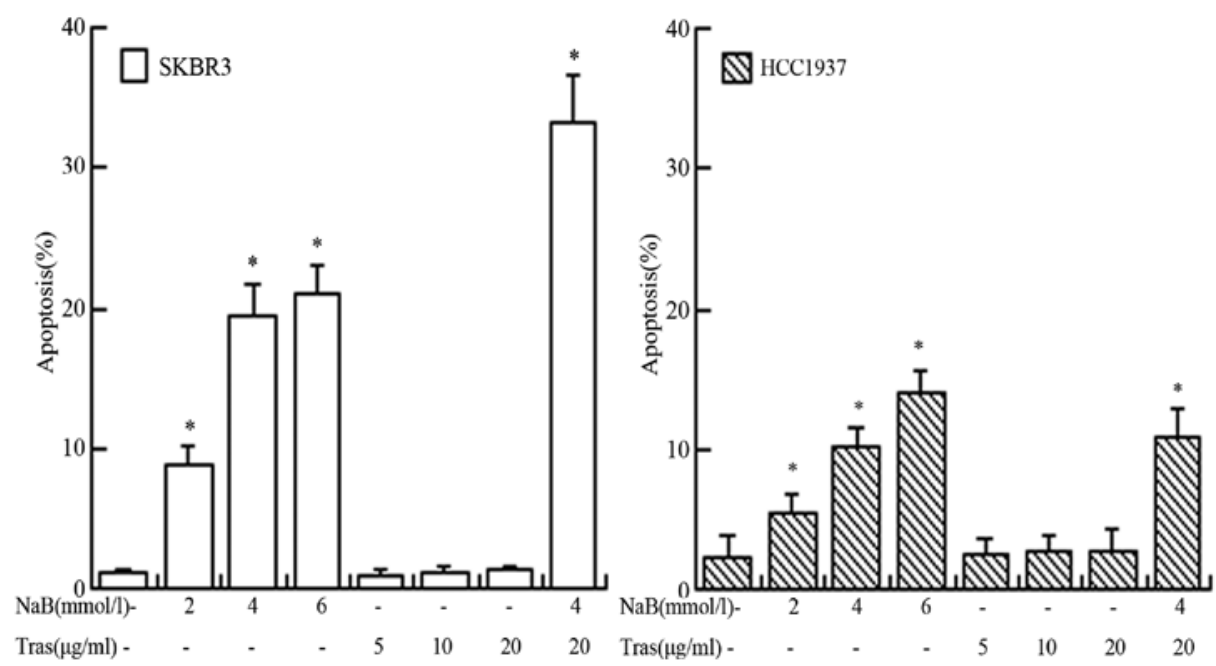

Figure 3. Flow cytometry analysis of the apoptosis rate of SKBR3 and HCC1937 cells treated with sodium butyrate (NaB) or/and trastuzumab (Tras) at the indicated concentrations. $\mathrm{NaB}$ induced apoptosis in a dose-dependent manner, however, there was no significant effect of trastuzumab on cell apoptosis Incubation of trastuzumab enhanced the apoptosis rate induced by NaB in the SKBR3, but not in the HCC1937 cell line. "Statistical significance (P<0.05) compared to control.

Table I. p27 ${ }^{\text {Kipl }}$ mRNA content in SKBR3 and HCC1937 cells after $48 \mathrm{~h}$ incubation with the indicated reagents.

\begin{tabular}{lrccc}
\hline & Control & $\mathrm{NaB}$ & Trastuzumab & NaB + trastuzumab \\
\hline SKBR3 & $80.31 \pm 3.80$ & $134.93 \pm 9.30^{\mathrm{a}}$ & $114.35 \pm 7.81^{\mathrm{a}}$ & $160.63 \pm 12.36^{\mathrm{a}}$ \\
HCC1937 & $182.33 \pm 3.77$ & $221.20 \pm 5.24^{\mathrm{a}}$ & $170.93 \pm 4.94$ & $224.04 \pm 5.66^{\mathrm{a}}$ \\
\hline
\end{tabular}

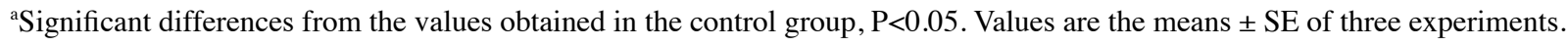

(S-phase) cells in the combination group was more than either reagent alone group (data not shown). The results suggest that the combination of $\mathrm{NaB}$ and trastuzumab inhibited cell cycle progression in SKBR3 cells at a greater degree.

Induction of apoptosis of SKBR3 and HCC1937 cell lines by treatment with $\mathrm{NaB}$ alone for $48 \mathrm{~h}$ occured in a dose-dependent manner. At the $\mathrm{NaB}$ concentrations of $0,2,4,6 \mathrm{mmol} / \mathrm{l}$, the apoptosis rate was $1.1 \pm 0.30,8.93 \pm 1.40,19.46 \pm 2.33$ and $20.9 \pm 2.27 \%$, respectively in SKBR3 cells, vs. $2.41 \pm 1.40$, $5.45 \pm 1.36,10.36 \pm 1.38$ and $13.96 \pm 1.71 \%$ in $\mathrm{HCC} 1937$ cells (Fig. 3). However, there was no significant effect of trastuzumab on cell apopotosis. Combination of $\mathrm{NaB}$ and trastuzumab for $48 \mathrm{~h}$ induced a higher degree of apoptosis in SKBR3 cells (Fig. 3) (33.25\% in SKBR3 vs. $10.8 \%$ in HCC1937 cells).

Effects of NaB and/or trastuzumab on mRNA and protein levels of $p 27^{K i p l}$. To investigate how trastuzumab improved the cell cycle and apoptotic effects of $\mathrm{NaB}$ on SKBR3 and HCC1937 cells, we examined the levels of p27 ${ }^{\text {Kipl }}$ mRNA and protein. First, we detected the mRNA and protein levels of HER2 in the control groups. Higher levels of HER2 mRNA and protein were detected in SKBR3 cells than in HCC1937 cells (Fig. 4A and B). On the other hand, the levels of p27 $7^{\text {Kipl }}$ were much lower in SKBR3 cells than in HCC1937 cells without treatment (Figs. 4C and 5) (Table I). p2 $7^{\text {Kipl }}$ mRNA and protein levels markedly increased in SKBR3 cells and HCC1937 cells with incubation with NaB. Trastuzumab also up-regulated the level of p27 $7^{\text {Kipl }}$ slightly in SKBR3 cells, but had no effect in $\mathrm{HCC} 1937$ cells. After co-treatment with $\mathrm{NaB}$ and trastuzumab, the expression of p2 $7^{\mathrm{Kipl}} \mathrm{mRNA}$ and protein increased notably in comparison to SKBR3 cells treated with $\mathrm{NaB}$ alone; however, no similar results were observed in HCC1937 cells, which are HER2-negative (Figs. 4C and $\mathrm{D}$ and 5) (Table I). In conclusion, a synergistic effect of the two reagents was found in the transcriptional and translational regulation of $\mathrm{p} 27^{\text {Kip1 }}$.

\section{Discussion}

The mainstream therapeutic strategies of breast cancer include surgical resection, traditional chemotherapy, endocrinotherapy and trastuzumab-mediated targeted therapy. Previous trials have demonstrated that the sequential addition of trastuzumab to chemotherapy could obviously improve disease-free survival (DFS), overall survival (OS) and event-free survival (EFS) in HER2-positive breast cancer patients (9).

Our present study demonstrates that a combination of $\mathrm{NaB}$ and trastuzumab exerts greater growth inhibitory effects than either reagent individually, and that the magnitudes of such effects correlated with the levels of HER2 expression. To elucidate the molecular mechanisms underlying the growth inhibition, we examined the effects of single reagents and the combination on cell cycle and apoptosis. We found that treatment with the combination caused an obvious enhancement 
A

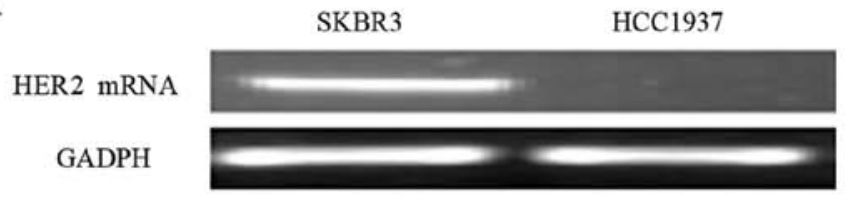

B

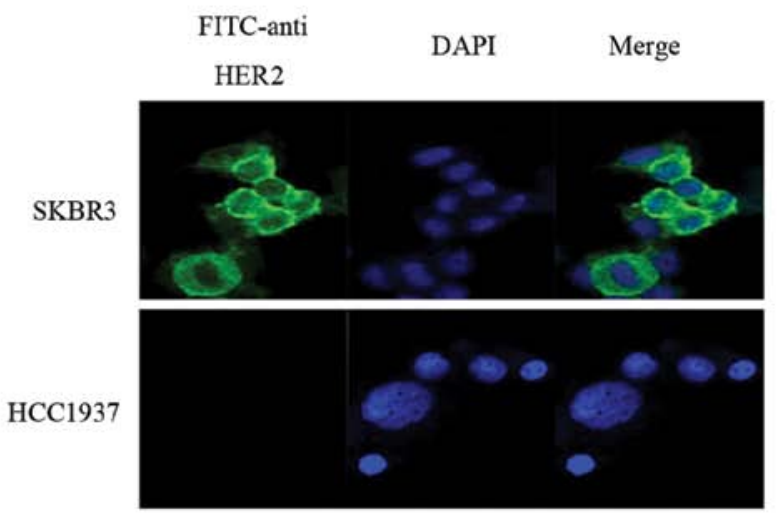

$\mathrm{C}$

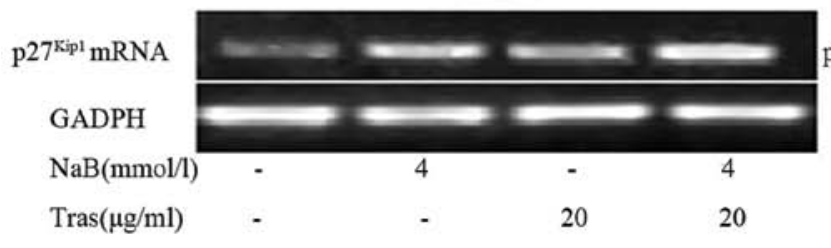

$\mathrm{D}$

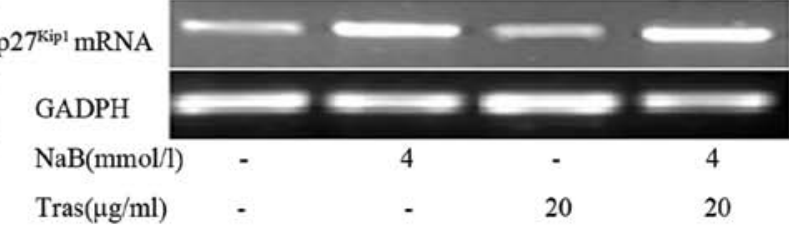

Figure 4. RT-PCR quantitation of $\mathrm{p} 27^{\mathrm{Kipl}} \mathrm{mRNA}$ level in SKBR3 and HCC1937 cells treated with sodium butyrate (NaB) or/and trastuzumab (Tras). (A) HER2 mRNA was detected by RT-PCR. Lane 1, SKBR3 cells; lane 2, HCC1937 cells. (B) HER2 protein expression in SKBR3 and HCC1937 cells was detected by immunofluorescence. (C and D) p27 ${ }^{\text {Kipl }}$ mRNA was detected by RT-PCR in SKBR3 and HCC1937 cell lines after various treatments. Lane 1, control; lane 2, treated with $\mathrm{NaB}$; lane 3, treated with trastuzumab; lane 4, treated with $\mathrm{NaB}$ and trastuzumab. GAPDH mRNA expression was used as the loading control.
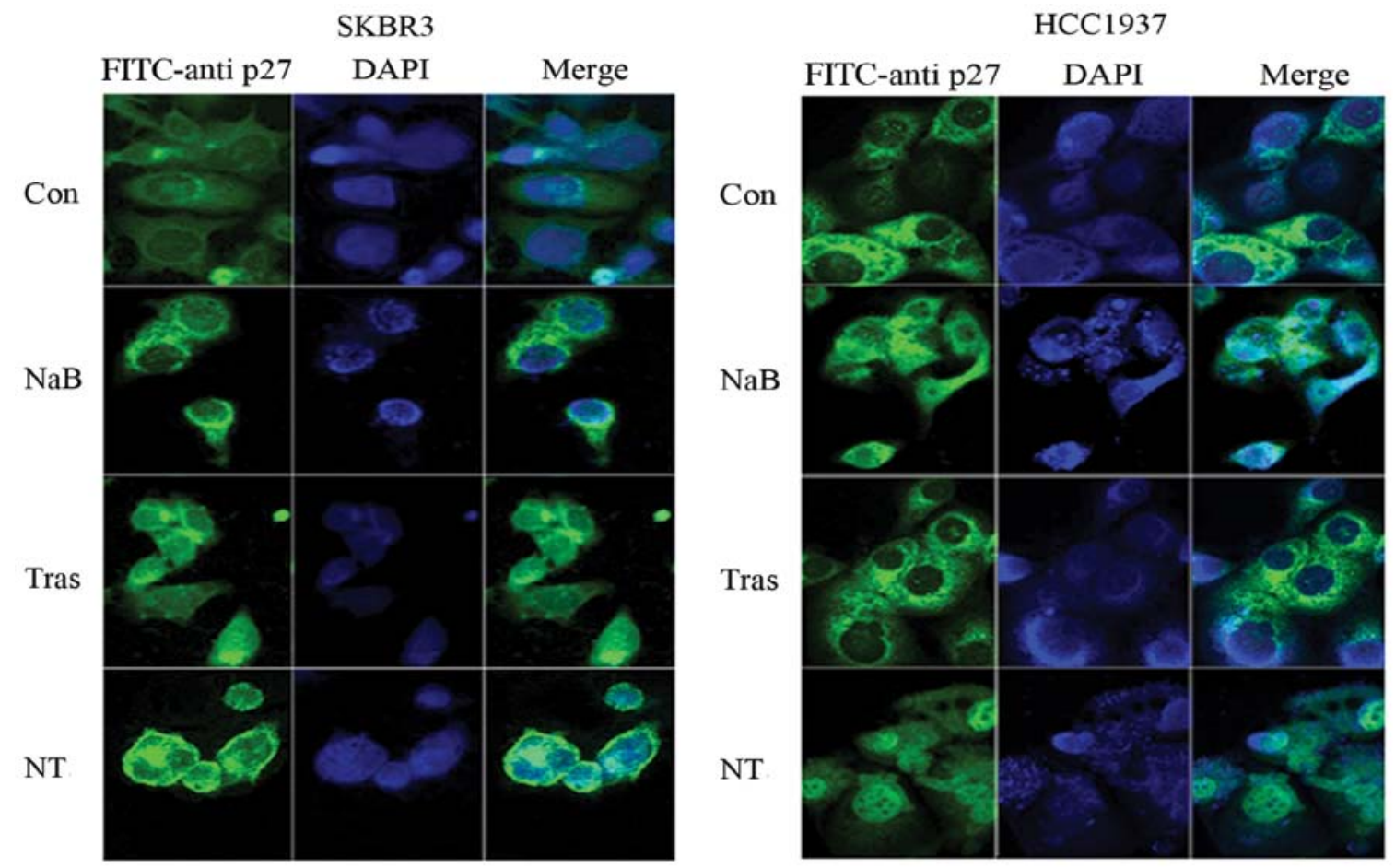

Figure 5. Immunofluorescence staining analysis of the expression of p27 $7^{\mathrm{Kip} 1}$ in the SKBR3 (left) and HCC1937 (right) cell lines treated with sodium butyrate $(\mathrm{NaB})$ or/and trastuzumab (Tras). Semi-quantitative analysis demonstrated that treatment with $4 \mathrm{mmol} / \mathrm{l} \mathrm{NaB}$ or $20 \mu \mathrm{g} / \mathrm{ml}$ trastuzumab for $48 \mathrm{~h}$ increased $\mathrm{p} 27^{\mathrm{Kip} 1}$ expression in SKBR3 cells, and the up-regulation of $\mathrm{p} 27^{\mathrm{Kipl}}$ expression was more significant in the combination group. However, this effect was not observed in HCC1937 cells, which are HER2-negative. 
of induction of cell cycle arrest and apoptosis, which was not observed with single trastuzumab treatment. A previous study reported that a certain concentration of trastuzumab for enough time may decelerate cell cycle progress and induce cells into quiescence by increasing expression of the genes HEC and DEEPEST $(10,11)$, mainly in the $\mathrm{G}_{2} / \mathrm{M}$ phase. The discrepancy here is possibly due to the fact that the continuous treatment of trastuzumab in our experiments was not long enough to result in cell cycle progression and apoptosis.

Histone deacetylation inhibitors are anti-neoplastic agents acting by net acetylation of core histones, causing the uncoiling of chromatin and activation of numerous genes implicated in the regulation of cell survival, growth, differentiation, cell cycle arrest and apoptosis $(7,8,12,13)$. The activity of $\mathrm{G}_{1} \mathrm{Cdks}$ is stringently regulated by $\mathrm{NaB}$ through association with specific $\mathrm{Cdk}$ inhibitors including the CIP/KIP family (p21 $1^{\text {Cipl/Waf1 }}, \mathrm{p} 27^{\text {Kip1 }}$ and $\mathrm{p} 57^{\mathrm{Kip} 2}$ ), which could bind all $\mathrm{G}_{1}$ cyclin-Cdk complexes $(8,14)$. Previous studies have shown that histone deacetylation inhibitor treatment could result in down-regulation of HER2 receptor-mediated signaling, as well as increase of p $27^{\text {Kipl }}$ levels and the cyclinE-Cdk2 complex binding (14-17). Trastuzumab also blocks the HER2 downstream signaling to influence the cell cycle and apoptosis (10). In addition, the effects of $\mathrm{NaB}$ and trastuzumab co-treatment may affect various pathways to up-regulate $\mathrm{p} 27^{\mathrm{Kipl}}$ or reduce its degradation.

p2 $7^{\mathrm{Kip} 1}$, a member of CIP/KIP family, plays a key role in cell proliferation, differentiation and apoptosis regulations. Numerous studies had demonstrated that low level expression of p27 was frequently detected in human cancers and correlated with cancer development and poor survival (18-20). We found that $\mathrm{p} 27^{\mathrm{Kip} 1} \mathrm{mRNA}$ levels were increased abundantly in the presence of $\mathrm{NaB}$ alone in breast cancer cell lines and up-regulated merely in the trastuzumab-treated SKBR3 cell line (Fig. 4). p2 $7^{\mathrm{Kip} 1}$ mRNA was increased most strikingly when treated with the combination of the two reagents. On one hand, HDACi inhibited the activity of HDACs, which interact with sequence-specific transcriptional factors on $\mathrm{p} 27^{\mathrm{Kip} 1}$ promoter and deacetylate promoter-bound histones (21-27). Therefore $\mathrm{NaB}$ could directly inhibit the HDACs of the p $27^{\mathrm{Kip} 1}$ promoter to cause an accumulation of acetylated histones for the access of basal transcriptional factors to the promoter, such as activating the binding of SP1 to proximal GC boxes (22-24), NF-Y to the CCAAT box (24), ectopic E2F to 5'-TTTG/CG/ CCGC-3' sequences $(25,28)$ and repressing the binding of c-Myc to Inr elements (27), NF-kB to 5'-GGGCTTCCCC-3' sequences (27). On the other hand, HDACi may indirectly block the pathway of AKT or ERK and affect the expression of c-Myc and FoxO factors which inhibited p27 $7^{\text {Kipl }}$ mRNA expression (28). The faint influence of trastuzumab on the transcription level of $\mathrm{p} 27^{\mathrm{Kipl}}$ was related to the pathways of the regulation system (28). As soon as trastuzumab binds the receptor, the PI3K/AKT or MEK/ERK pathway is blocked, and p $27^{\text {Kip1 }}$ mRNA could be up-regulated. The post-transcriptional regulation is also important. In our results, the fluorescence of $\mathrm{p} 27^{\mathrm{Kip} 1}$ protein was higher in fresh HCC1937 cells than SKBR3 cells. After treatment with $\mathrm{NaB}$ alone, $\mathrm{p} 27^{\mathrm{Kip} 1}$ protein was up-regulated, noticeably in SKBR3 cells. Trastuzumabtreatment induced the transfer of $\mathrm{p} 27^{\mathrm{Kip} 1}$ protein certainly into the nucleus only in the SKBR3 cell lines. These results suggested that the status of HER2 was inversely correlated with expression of $\mathrm{p} 27^{\mathrm{Kip} 1}$ protein in breast cancer cells. It was likely that HER2 took part in modulation of p $27^{\text {Kip } 1}$ protein in different manners: overexpression and activation of HER2 clearly decreased the half-life of $\mathrm{p} 27^{\mathrm{Kip} 1}$. Furthermore, HER2 oncogenic signals down-regulated $\mathrm{p} 27^{\mathrm{Kip} 1}$ protein to enhance ubiquitin-mediated degradation by increasing affinity with JAB1 through the HER2/Grb2/Ras/MAPK pathway $(29,30)$, promoting $\mathrm{p} 27^{\mathrm{Kip} 1}$ protein binding to ubquitin $\mathrm{SCF}^{\mathrm{SKP} 2}$, and regulating the stability of $\mathrm{p} 27^{\mathrm{Kip} 1}$ protein by MIRK/DYRK1B. It is possible that either $\mathrm{NaB}$ or trastuzumab may block the HER2 signals to release the restraint of $\mathrm{p} 27^{\mathrm{Kip} 1}$ protein expression and affect the proliferation of cancer cells $(28,31)$.

In conclusion, trastuzumab significantly synergized with $\mathrm{NaB}$ in the inhibition of cell proliferation and the promotion of cell cycle arrest and cell apoptosis by up-regulating $\mathrm{p} 27^{\mathrm{Kip} 1}$ in a HER2-overexpressing breast cancer cell line in vitro. Although these data need to be verified in animal or clinical studies, our results may provide the basis for the development of better approaches for breast caner therapy.

\section{Acknowledgements}

This study was supported in part by the National Natural Science Foundation Grants nos. 30870962 and 30470669 (X.G.) and by the General Hospital of Nanjing Military Area Grants no. 2009M013.

\section{References}

1. Le XF, Mao W, Lu C, Thornton A, Heymach JV, Sood AK and Bast RC Jr: Specific blockade of VEGF and HER2 pathways results in greater growth inhibition of breast cancer xenografts that overexpress HER2. Cell Cycle 7: 3747-3758, 2008.

2. Ritter CA, Perez-Torres M, Rinehart C, Guix M, Dugger T, Engelman JA and Arteaga CL: Human breast cancer cells selected for resistance to trastuzumab in vivo overexpress epidermal growth factor receptor and ErbB ligands and remain dependent on the ErbB receptor network. Clin Cancer Res 13: 4909-4919, 2007.

3. Nahta R, Takahashi T, Ueno NT,Hung MC and Esteva FJ: P27(kipl) down-regulation is associated with trastuzumab resistance in breast cancer cells. Cancer Res 64: 3981-3986, 2004.

4. Guarneri V, Barbieri E, Dieci MV, Piacentini F and Conte P: Anti-HER 2 neoadjuvant and adjuvant therapies in HER2 positive breast cancer. Cancer Treat Rev 3: 62-66, 2010.

5. Gianni L, Eiermann W, Semiglazov V, et al: Neoadjuvant chemotherapy with trastuzumab followed by adjuvant trastuzumab versus neoadjuvant chemotherapy alone, in patients with HER2-positive locally advanced breast cancer (the NOAH trial): a randomised controlled superiority trial with a parallel HER2-negative cohort. Lancet 375: 377-384, 2010.

6. Baselga J: Treatment of HER2-overexpressing breast cancer. Ann Oncol 21: 36-40, 2010.

7. Lane AA and Chabner BA: Histone deacetylase inhibitors in cancer therapy. J Clin Oncol 27: 5459-5468, 2009.

8. Jazirehi AR: Regulation of apoptosis-associated genes by histone deacetylase inhibitors: implications in cancer therapy. Anticancer Reagents 21: 805-813, 2010.

9. Verma S, Lavasani S, Mackey J, et al: Optimizing the management of Her2-positive early breast cancer: the clinical reality. Curr Oncol 17: 20-33, 2010.

10. Lane HA, Beuvink I, Motoyama AB, Daly JM, Neve RM and Hynes NE: ErbB2 potentiates breast tumor proliferation through modulation of p27(Kip1)-Cdk2 complex formation: receptor overexpression does not determine growth dependency. Mol Cell Biol 20: 3210-3223, 2000.

11. Le XF, Lammayot A, Gold D, et al: Genes affecting the cell cycle, growth, maintenance, and reagent sensitivity are preferentially regulated by anti-HER 2 antibody through phosphatidylinositol 3-kinase-AKT signaling. J Biol Chem 280: 2092-2104, 2005. 
12. Küster K, Grötzinger C, Koschel A, Fischer A, Wiedenmann B and Anders M: Sodium butyrate increases expression of the coxsackie and adenovirus receptor in colon cancer cells. Cancer Invest 28 : 268-274, 2010

13. Emlet DR, Brown KA, Kociban DL, Pollice AA, Smith CA, Ong BB and Shackney SE: Response to trastuzumab, erlotinib, and bevacizumab, alone and in combination, is correlated with the level of human epidermal growth factor receptor-2 expression in human breast cancer cell lines. Mol Cancer Ther 6: 2664-2674, 2007.

14. Chen JS, Faller DV and Spanjaard RA: Short-chain fatty acid inhibitors of histone deacetylases: promising anticancer therapeutics? Curr Cancer Reagent Targets 3: 219-236, 2003.

15. Nolan L, Johnson PW, Ganesan A, Packham G and Crabb SJ: Will histone deacetylase inhibitors require combination with other agents to fulfill their therapeutic potential? Br J Cancer 99: 689-694, 2008

16. Fuino L, Bali P, Wittmann S, et al: Histone deacetylase inhibitor LAQ824 down-regulates Her-2 and sensitizes human breast cancer cells to trastuzumab, taxotere, gemcitabine, and epothilone B. Mol Cancer Ther 2: 971-984, 2003.

17. Mahboobi S, Sellmer A, Winkler M, et al: Novel chimeric histone deacetylase inhibitors: a series of lapatinib hybrides as potent inhibitors of epidermal growth factor receptor (EGFR), human epidermal growth factor receptor 2 (HER2), and histone deacetylase activity. J Med Chem 53: 8546-8555, 2010.

18. Polyak K, Lee MH, Erdjument-Bromage H, Koff A, Roberts JM Tempst $\mathrm{P}$ and Massagué J: Cloning of $\mathrm{p} 27^{\mathrm{Kipl}}$, a cyclin-dependent kinase inhibitor and a potential mediator of extracellular antimitogenic signals. Cell 78: 59-66, 1994.

19. Guan X, Chen L, Wang J, et al: Mutations of phosphorylation sites Ser10 and Thr187 of $\mathrm{p}^{\mathrm{K}} \mathrm{K}^{\mathrm{ip1}}$ abolish cytoplasmic redistribution but do not abrogate $\mathrm{G}_{0 / 1}$ phase arrest in the HepG2 cell line. Biochem Biophys Res Commun 347: 601-607, 2006.

20. Guan X, Wang Y, Xie R, et al: $\mathrm{p} 27^{\mathrm{Kip} 1}$ as a prognostic factor in breast cancer: a systematic review and meta-analysis. J Cell Mol Med 14: 944-953, 2010

21. Kim S, Kang JK, Kim YK, et al: Histone deacetylase inhibitor apicidin induces cyclin E expression through Spl sites. Biochem Biophys Res Commun 342: 1168-1173, 2006.
22. Schnur N, Seuter S, Katryniok C, Rådmark O and Steinhilber D: The histone deacetylase inhibitor trichostatin A mediates upregulation of 5-lipoxygenase promoter activity by recruitment of Sp1 to distinct GC-boxes. Biochim Biophys Acta 1771: 1271-1282, 2007.

23. Pan L, Pan H, Jiang H, Du J, Wang X, Huang B and Lu J: HDAC4 inhibits the transcriptional activation of mda-7/IL-24 induced by Sp1. Cell Mol Immunol 7: 221-226, 2010.

24. Campanero MR, Herrero A and Calvo V: The histone deacetylase inhibitor trichostatin A induces GADD45 gamma expression via Oct and NF-Y binding sites. Oncogene 27: 1263-1272, 2008.

25. Abramova MV, Pospelova TV, Nikulenkov FP, Hollander CM, Fornace AJ Jr and Pospelov VA: $\mathrm{G}_{1} / \mathrm{S}$ arrest induced by histone deacetylase inhibitor sodium butyrate in E1A + Ras-transformed cells is mediated through down-regulation of E2F activity and stabilization of beta-catenin. J Biol Chem 281: 21040-21051, 2006.

26. Marshall GM, Gherardi S, Xu N, et al: Transcriptional upregulation of histone deacetylase 2 promotes Myc-induced oncogenic effects. Oncogene 29: 5957-5968, 2010.

27. Domingo-Domènech J, Pippa R, Tápia $M$, Gascón $P$, Bachs $O$ and Bosch M: Inactivation of NF-kappaB by proteasome inhibition contributes to increased apoptosis induced by histone deacetylase inhibitors in human breast cancer cells. Breast Cancer Res Treat 112. 53-62, 2008.

28. Bagui TK, Cui D, Roy S, Mohapatra S, Shor AC, Ma L and Pledger WJ: Inhibition of $\mathrm{p} 27^{\mathrm{Kip} 1}$ gene transcription by mitogens. Cell Cycle 8: 115-124, 2009.

29. Yang HY, Zhou BP, Hung MC and Lee MH: Oncogenic signals of HER2/neu in regulating the stability of the cyclin-dependent kinase inhibitor p27. J Biol Chem 275: 24735-24739, 2000.

30. Hsu MC, Chai CY, Hou MF, Chang HC, Chen WT and Hung WC: Jab1 is overexpressed in human breast cancer and is a downstream target for HER2/neu. Mod Pathol 21: 609-616, 2008.

31. Le XF, Pruefer F and Bast RC Jr: HER2-targeting antibodies modulate the cyclin-dependent kinase inhibitor $\mathrm{p} 27^{\mathrm{Kipl}}$ via multiple signaling pathways. Cell Cycle 4: 87-95, 2005. 